\title{
Perunan maltokaariviruksen leviäminen perunakasvin eri osiin
}

\author{
Johanna Aura ja Jari P. T. Valkonen
}

Soveltavan biologian laitos, PL 27, 00014 Helsingin yliopisto

Perunan maltokaarivirus (Potato mop-top virus, PMTV) on Pohjoismaissa laajalle levinnyt ja vaikeasti torjuttava maalevintäinen taudinaiheuttaja. Sen levittäjänä pellolla toimii sienenkaltainen mikrobi, Spongospora subterranea, joka aiheuttaa mukuloiden pintaan kuorirokkoa. PMTV aiheuttaa mukuloihin kuoliota, maltokaarioireita, ja tuottaa siten laatutappioita.

PMTV tartuttaa mukuloita ja perunan juuristoa, mutta se havaitaan harvoin maanpäällisissä osissa kuten lehdissä. Siten PMTV-tartunnan havaitseminen perunakasvustossa kasvukauden aikana tai testaaminen idätettyjen mukuloiden versoista ei ole mahdollista samaan tapaan kuin muiden perunanvirusten osalta. Havaintojemme mukaan PMTV kuitenkin leviää mukulasta ituihin varastooloissa $\left(5^{\circ} \mathrm{C}\right.$, pimeä). Tämä viittaa siihen, että virus kykenisi sinänsä leviämään kehittyviin versoihin, mutta leviäminen estyy vielä tuntemattoman mekanismin vaikutuksesta. Tutkimuksemme tavoitteena oli selvittää tätä mekanismia.

Kasvatushuonekokeissa PMTV:n havaittiin leviävän infektoituneesta siemenmukulasta kaikkiin perunan maanalaisiin osiin: juuriin, maavarsiin sekä niihin muodostuviin mukuloihin. Lehdissä virusta oli vain hyvin vähäisiä määriä, jotka olivat niin pieniä, että ne voitiin havaita vain testaamalla virusgenomin (RNA) läsnäoloa kvantitatiivisen PCR-menetelmän avulla, mutta ei virustestaukseen normaalisti käytettävän, vasta-aineisiin perustuvan ELISA-menetelmän avulla. Itävien mukuloiden altistaminen valolle ja korkeammalle lämpötilalle johti virusmäärien vähentymiseen iduissa. Näiden tulosten pohjalta tarkastellaan lähemmin virus-RNA:han kohdentuvaa hajotusta, ns. RNA-hiljennystä, mahdollisena mekanismina, joka estää PMTV:n kerääntymistä perunan yhteyttäviin osiin.

Asiasanat: Perunan maltokaarivirus, PMTV, RNA-hiljennys 


\section{Johdanto}

Perunan maltokaarivirus (Potato mop-top virus; PMTV) on maalevintäinen virus, joka aiheuttaa nekroottisia maltokaarioireita mukuloissa (Calvert ja Harrison 1966) (Kuva 1.). Maltokaarioireet muistuttavat TRV:n (Tobacco rattle virus) aiheuttamia oireita. Oireiden perusteella nämä perunan mukulaa vahingoittavat virustaudit onkin vaikeaa erottaa toisistaan (Calvert ja Harrison 1966, Nielsen ja Mølgaard 1997).

Maltokaarivirus leviää perunan kuorirokkoa aiheuttavan sienenkaltaisen maamikrobin [Spongospora subterranea (Wallr.) Lagerh.] parveiluitiöissä (Jones ja Harrison 1969, Harrison ja Jones 1970). S. subterranea muodostaa lepoitiöitäkin, joihin päästyään maltokaarivirus säilyy tartutuskykyisenä niin pitkään kuin lepoitiötkin, jopa toistakymmentä vuotta (Jones ja Harrison 1969). Kun maltokaarivirus ja sen vektori ovat kerran levinneet pellolle, niistä on käytännössä mahdotonta päästä eroon. Ongelmaa pahentaa se, että maltokaarivirukselle täysin kestäviä perunalajikkeita ei ole saatavilla (Sandgren 1995, Nielsen ja Mølgaard 1997, Sandgren et al. 2002). Eri perunalajikkeissa oireiden määrä saattaa vaihdella paljonkin (Kurppa 1989b), mutta viroottiset mululat voivat olla myös oireettomia. Kaikki oireiden muodostukseen vaikuttavat seikat eivät ole vielä selvillä. Nykyään ainoa maltokaariviruksen torjuntakeino on terveen siemenperunan käyttö. Tärkeää on myös estää kuorirokkosienen leviäminen pellolta toiselle maa-aineksen mukana.

Maltokaarivirusta esiintyy kaikissa Pohjoismaissa. Norjassa virus havaittiin ensimmäisen kerran 1960-luvulla (Björnstad 1969) ja Suomessa, Ruotsissa sekä Tanskassa 1980-luvulla (Ryden et al. 1986, Kurppa 1989a, Nielsen ja Mølgaard 1997). Sen aiheuttama maltokaarioire on nykyään yksi pahimmista laatuongelmista Pohjoismaisessa perunateollisuudessa.

Maltokaarivirus aiheuttaa harvoin oireita perunan lehdissä, vaikka sen englanninkielinen nimi (Potato mop-top virus) juontuukin siitä, että perunan versot saattavat virusinfektion seurauksena muuttua puskamaisiksi (Calvert ja Harrison 1966). Virusta ei useimmiten pystytä havaitsemaan perunan lehdistä virustestaukseen normaalisti käytettävällä vasta-aineisiin perustuvalla ELISAmenetelmällä. Havaintojemme mukaan maltokaarivirus voidaan kuitenkin havaita ELISA-testillä pimeässä kasvaneissa perunan iduissa. Tämä viittaa siihen, että maltokaarivirus kykenee siirtymään perunan kehittyviin versoihin, mutta jokin mekanismi kuitenkin estää viruksen tehokkaan leviämisen tai lisääntymisen versoissa. Tutkimuksen tarkoituksena oli selvittää kyseistä mekanismia. Samalla haluttiin selvittää puhtaan siemenperunan merkitystä perunan viljelyssä tutkimalla, mihin kasvinosiin maltokaarivirus leviää infektoituneesta emomukulasta ilman vektorinsa läsnäoloa.

Tämä tutkimus on tehty osana laajaa tutkimushanketta, jonka tarkoituksena on kartoittaa perunan maltokaariviruksen esiintymistä Itämeren ympärysmaissa sekä kehittää maltokaariviruksen hallintakeinoja. Tutkimushankkeeseen osallistuu yliopistoja, tutkimuslaitoksia sekä kasvintarkastusviranomaisia kaikista Itämeren ympärysmaista.

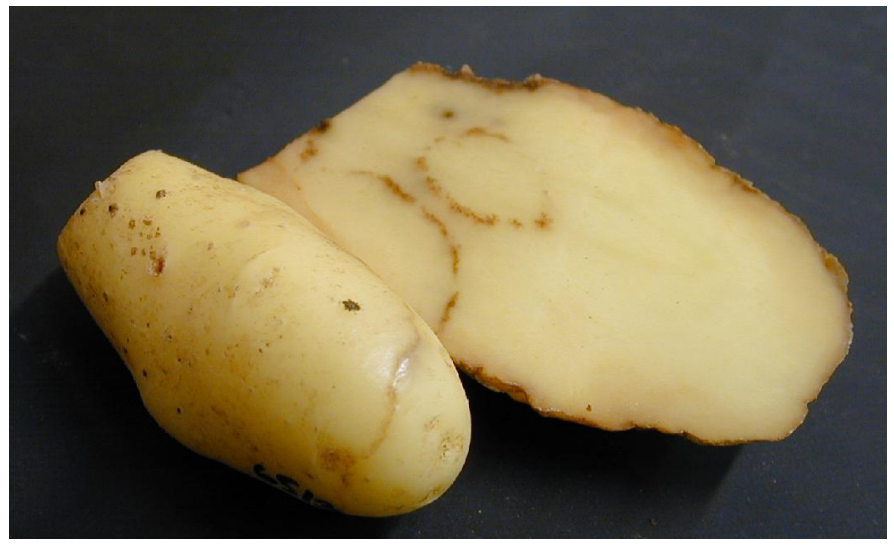

Kuva 1. Pinnallisia (vasemmanpuoleinen mukula) ja sisäisiä (oikenpuoleinen mukula) maltokaarivirusoireita perunan mukuloissa. 


\section{Aineisto ja menetelmät}

Kaikki tutkimuksessa käytetyt mukulat saatiin Maa- ja elintarviketalouden tutkimuskeskuksesta Jokioisilta. Mukulat testattiin ELISA-testillä maltokaariviruksen havaitsemiseksi ja vain infektoituneet mukulat otettiin mukaan tutkimukseen. Koe tehtiin kolmessa osassa siten, että kokeessa A olivat lajikkeet 'Tanu' ja 'Seresta', kokeessa B lajikkeet 'Tanu', 'Seresta' ja 'Annabelle' (10 mukulaa/lajike), ja kokeessa C lajikkeet 'Van Gogh' (5 mukulaa), 'Annabelle' (1 mukula) ja 'Seresta' (1 mukula).

Kaikki mukulat varastoitiin pimeässä $\left(5^{\circ} \mathrm{C}\right)$. Kokeen alussa osa mukuloista siirrettiin lämpimään $\left(16^{\circ} \mathrm{C}\right)$, mutta pidettiin yhä pimeässä. Kymmenen vuorokauden päästä osa kylmässä säilytetyistä ja osa lämpökäsittelyn saaneista mukuloista altistettiin valolle $\left(30 \mu \mathrm{mol} / \mathrm{s} / \mathrm{m}^{2}\right)$. Mukuloista otettiin itunäytteitä ennen kokeen aloitusta, 10 vrk lämpökäsittelyn jälkeen sekä 6 h, 24 h ja 3 vrk valokäsittelyn aloittamisesta. Itunäytteet otettiin siten, että pimeässä pidetyt idut eivät missään vaiheessa altistuneet valolle. Kaikki näytteet jäädytettiin nestetypessä ja säilytettiin $-70^{\circ} \mathrm{C}$. Kokeissa $\mathrm{A}$ ja $\mathrm{B}$ näytteeksi otettiin kokonainen itu (eri itu jokaisella näytteenottokerralla), mutta kokeessa $\mathrm{C}$ käytettiin hyväksi itujen haaroittumista ja näytteeksi otettiin kullakin kertaa eri idunhaara. Tällöin pystyttiin seuraamaan viruspitoisuuksien vaihteluita samassa idussa.

Mukulat istutettiin käsittelyiden jälkeen kasvatushuoneeseen omiin ruukkuihinsa. Käytetty turve oli steriloitu kahteen kertaan. Kasvatushuoneen lämpötila oli $24^{\circ} \mathrm{C}$ ja valon intensiteetti oli 200 $\mu \mathrm{mol} / \mathrm{s} / \mathrm{m}^{2}$ kasvin tyven tasalla.

Lehti- ja juurinäytteet kerättiin yhden ja kahden kuukauden kuluttua istutuksesta. Maavarsinäytteet ja mukulat kerättiin sadonkorjuun yhteydessä (n. 3 kk istutuksesta). Lehti-, juuri- ja maavarsinäytteet jäädytettiin nestetypessä ja säilytettiin $-70^{\circ} \mathrm{C}$. Mukulat säilytettiin $5^{\circ} \mathrm{C}$.

Lehti- ja juurinäytteistä havainnoitiin maltokaarivirusta vasta-aineisiin perustuvan ELISA testin avulla. Näytteet jauhettiin eristyspuskurissa $(500 \mathrm{mM}$ Tris- $\mathrm{HCl} \mathrm{pH}$ 7.4, 2\% PVP-40, $1 \%$ PEG $6000,140 \mathrm{mM} \mathrm{NaCl}, 0,05 \%$ Tween-20) ja $100 \mu$ l tätä homogenaattia pipetoitiin kahteen kaivoon 96kuoppalevylle. Levyn kuopat oli esipäällystetty PMTV-kuoriproteiinia vastaan tuotetulla monoklonaalisella vasta-aineella (PMTV Mab, SASA, Skotlanti), joka oli laimennettu (1:1000) puskurilla (15 mM Na $\mathrm{CO}_{3}, 34.5 \mathrm{mM} \mathrm{NaHCO} 3, \mathrm{pH}$ 9.6). Levyä inkuboitiin yön yli $\left(4^{\circ} \mathrm{C}\right)$. Levyt

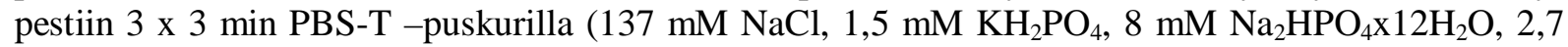
$\mathrm{mM} \mathrm{KCl} \mathrm{pH} \mathrm{7,4} \mathrm{ja} \mathrm{0,005} \mathrm{\%} \mathrm{Tween-20).} \mathrm{Levylle} \mathrm{lisättiin} \mathrm{alkaliinifosfataasilla} \mathrm{konjukoitu} \mathrm{vasta-aine}$ (PMTV-AP, SASA, Skotlanti) ja kahden tunnin inkubaation $\left(37^{\circ} \mathrm{C}\right)$ jälkeen levy pestiin jälleen. Levylle lisättiin substraatti $(0,25 \mathrm{mg}$ p-nitrofenyylifosfaattia / $\mathrm{ml}$ substraattipuskuria $(97 \mathrm{ml}$ dietanolamiinia, $900 \mathrm{ml} \mathrm{H}_{2} \mathrm{O}, \mathrm{pH} \mathrm{9.8)}$ ) ja värin kehittymistä seurattiin spektrofotometrillä (ELISAlukulaitteella) (Benchmark, Bio-Rad) mitaten aallonpituudella $405 \mathrm{~nm}$. Näytteet, joiden absorbanssi oli suurempi kuin viruksettoman näytteen avulla laskettu raja-arvo ( 2 kertaa negatiivisten näytteiden absorbanssien keskiarvo + keskihajonta), katsottiin positiivisiksi.

Mukulanäytteet tutkittiin immunosieppaus-käänteiskopiointi-PCR:n (IC-RT-PCR) avulla. Mukulanäytteet murskattiin edellä kuvatussa eristyspuskurissa ja näytettä pipetoitiin $100 \mu$ PMTV Mab:llä (1:150 coating-puskurissa) päällystettyihin 0,5 ml PCR -putkiin. Putkia inkuboitiin $60 \mathrm{~min}$ $37^{\circ} \mathrm{C}$ ja ne pestiin kuten edellä on mainittu. Lopuksi putket pestiin vielä nukleaasittomalla vedellä. Putkiin sidottu viruksen RNA käännettiin cDNA:ksi käyttäen 3'rev aluketta (TGGTCTTGGATACCCTCCAAG), joka sitoutuu virus-RNA:n 3' päähän, sekä SuperScript III (Invitrogen) entsyymiä valmistajan ohjeiden mukaan. Saatua cDNA:ta käytettiin PCR reaktiossa käyttäen kuoriproteiinia tuottavalle alueelle suunniteltuja alukkeita (CP1 GGTTTGTTTACCACCCTTGG ja Rpr24 TCCCTGTCACCTTCATCTATGG) sekä Phusion DNA polymeraasia (Finnzymes) valmistajan ohjeiden mukaan. Infektoituneista mukuloista monistuu PCR:ssä 1248 emäsparin mittainen tuote. Terveistä mukuloista ei monistu tuotetta.

Itunäytteet, maavarsinäytteet ja osa lehtinäytteistä tutkittiin eristämällä RNA, tuottamalla siitä cDNA ja testaamalla sitä PCR- tai kvantitatiivista reaaliaikaista PCR-menetelmää (qPCR) käyttäen. Tätä varten näytteistä eristettiin RNA:ta Trizol -menetelmällä (Caldo et al. 2004). RNA käsiteltiin DNaasilla ja käännettiin cDNA:ksi M-MLV transkriptioentsyymillä (Promega) valmistajan ohjeiden mukaan. Maavarsinäytteet tutkittiin käyttäen samaa PCR reaktiota kuin edellä. Kvantitatiivisessa PCR:ssä (itu- ja lehtinäytteet) käytettiin alukkeita, jotka tunnistavat viruksen kuoriproteiinialueen (RTCP-F TTACGATCAATTCTCAGCTCAGTT, RT-CP-R CCTGGCTCAACACGCTAGTG), sekä 
DyNAmo HS SYPR Green qPCR Kittiä (Finnzymes). Kvantitatiivinen PCR tehtiin ja tulokset käsiteltiin käyttäen ABI Prism 7700 Sequence detection -systeemiä (Applied Biosystems).

\section{Tulokset ja tulosten tarkastelu}

\section{Viruspitoisuuden muutokset iduissa}

PMTV havaittiin kaikissa testatuissa iduissa ennen lämpökäsittelyä. Pimeässä tapahtuneen lämpökäsittelyn seurauksena havaittiin viruspitoisuuden nousseen viidessä idussa. Kun idut altistettiin valolle, nousi viruspitoisuus aluksi edelleen viidessä idussa seitsemästä, mutta kaikissa iduissa yhtä lukuun ottamatta viruspitoisuus lähti laskuun, kun valokäsittelyä jatkettiin (3 vrk). Neljässä idussa viruspitoisuus oli selvästi vähentynyt, mutta kahdessa idussa viruspitoisuus väheni vain lievästi. Koko kokeen ajan kylmässä pidetyissä iduissa havaittiin viruspitoisuuden nousevan valokäsittelyn aikana. Tämä saattoi johtua valon lämmittävästä vaikutuksesta, joka lämpökäsittelyn tavoin nosti viruspitoisuutta. Kylmässä ja pimeässä pidetyissä iduissa havaittiin vain vähäisiä muutoksia viruspitoisuudessa. Tulosten perusteella viruspitoisuus iduissa nousee lämpötilan noustessa, mikä on aiemmin osoitettu perunan mukuloilla (Kurppa 1989b). Kun idut altistettiin valolle, alkoi viruspitoisuus kuitenkin lämmön ja valon yhteisvaikutuksesta laskea. Lämpö ja valo ilmeisesti aikaansaavat sen, että perunan itu pystyy paremmin puolustautumaan virusta vastaan.

\section{Lehtien viruspitoisuus}

Maltokaarivirus havaittiin ELISA-testin avulla vain kahdesta lehtinäytteestä, jotka oli otettu kuukauden kuluttua istutuksesta (n. 14 vrk kuluttua taimettumisesta). Kahden kuukauden kuluttua otetuista näytteistä yhdessäkään ei havaittu PMTV:tä ELISA-testin avulla. Maltokaariviruksen läsnäolo lehdissä todettiin kuitenkin qPCR-menetelmällä. Nämä tulokset osoittavat, että maltokaarivirus kykenee leviämään myös perunan lehtiin, mutta sen pitoisuus niissä pysyy erittäin matalana.

\section{Juurten tartunta}

Maltokaarivirus havaittiin kuukauden kuluttua istutuksesta monien kasvien juurissa, mutta kahden kuukauden kuluttua vain muutamien kasvien juurissa (Taulukko 1). Vain lajikkeessa 'Van Gogh' infektoituneiden juurten määrä nousi ajan kuluessa.

Taulukko 1. Niiden maltokaariviruksen (PMTV) tartuttamien siemenmukuloiden osuus, joiden tuottamien kasvien juuret sisälsivät ELISA-menetelmällä havaittavia PMTV-pitoisuuksia. A, B ja C ovat erillisiä kokeita.

\begin{tabular}{|c|c|c|c|c|c|c|c|c|c|c|}
\hline & \multicolumn{5}{|c|}{$1 \mathrm{kk}$ istutuksesta } & \multicolumn{5}{|c|}{$2 \mathrm{kk}$ istutuksesta } \\
\hline & A & B & $\mathrm{C}$ & Yhteensä & $\%$ & A & B & $\mathrm{C}$ & yhteensä & $\%$ \\
\hline Tanu & - & $7 / 10$ & - & $7 / 10$ & 70 & $0 / 10$ & $1 / 10$ & - & $1 / 20$ & 5 \\
\hline Seresta & - & $4 / 10$ & $0 / 1$ & $4 / 11$ & 36 & $0 / 10$ & $0 / 10$ & $1 / 1$ & $1 / 21$ & 5 \\
\hline Annabelle & - & $2 / 10$ & $0 / 1$ & $3 / 11$ & 3 & $0 / 10$ & $0 / 10$ & $0 / 1$ & $0 / 21$ & 0 \\
\hline Van Gogh & - & - & $0 / 5$ & $0 / 5$ & 0 & - & - & $2 / 5$ & $2 / 5$ & 40 \\
\hline Yhteensä & - & $13 / 30$ & $0 / 7$ & $14 / 37$ & 38 & $0 / 30$ & $1 / 30$ & $3 / 7$ & $5 / 67$ & 13 \\
\hline
\end{tabular}

\section{Maavarret}

Maltokaarivirus havaittiin lähes kaikkien kasvien maavarsista. Vain yhden Annabelle-lajikkeen mukulasta kasvaneen kasvin maavarsista ei havaittu virusta.

\section{Mukulat}

Kaikki tutkimuksessa käytetyt lajikkeet tuottivat ainakin joitakin maltokaariviruksella infektoituneita tytärmukuloita, kun siemenperuna oli viroottinen (Taulukko 2). Virus näytti kuitenkin leviävän epätasaisesti emomukuloista tytärmukuloihin. Jotkin mukulat tuottivat ainoastaan infektoituneita tytärmukuloita, kun taas toiset saattoivat tuottaa ainoastaan terveitä mukuloita. Tanu-lajikkeen 
emomukuloista $25 \%$ tuotti ainoastaan infektoituneita mukuloita ja $40 \%$ ainoastaan terveitä mukuloita. Seresta-lajikkeella $5 \%$ emomukuloista tuotti vain infektoituneita mukuloita ja $25 \%$ ainoastaan terveitä mukuloita. Annabelle-lajikkeen mukuloista $10 \%$ tuotti vain terveitä mukuloita, kun taas toiset $10 \%$ tuotti ainoastaan infektoituneita mukuloita. Van Gogh-lajikkeesta yksikään mukula ei tuottanut ainoastaan infektoituneita tytärmukuloita, ja lisäksi $80 \%$ mukuloista tuotti vain terveitä satomukuloita. Tulokset osoittivat, että maltokaarivirus leviää emomukulasta tytärmukuloihin ilman S. spongospora -vektorin läsnäoloa, mutta virus ei kuitenkaan välttämättä siirry kaikkiin tytärmukuloihin.

Taulukko 2. Viroottisten mukuloiden osuus sadosta, kun siemenmukula on maltokaariviruksen tartuttama. A, B ja $\mathrm{C}$ ovat erillisiä kokeita.

\begin{tabular}{|c|c|c|c|c|c|}
\hline Lajike & A & B & C & Yhteensä & $\%$ \\
\hline Tanu & $17 / 30$ & $7 / 30$ & - & $24 / 60$ & $\mathbf{4 0}$ \\
\cline { 1 - 4 } Seresta & $10 / 30$ & $13 / 27$ & $0 / 3$ & $23 / 60$ & $\mathbf{3 8}$ \\
\hline Annabelle & - & $15 / 30$ & $0 / 3$ & $15 / 33$ & $\mathbf{4 5}$ \\
\hline Van Gogh & - & - & $2 / 15$ & $2 / 15$ & $\mathbf{1 3}$ \\
\hline
\end{tabular}

\section{Johtopäätökset}

Maltokaarivirus levisi melko tehokkaasti siemenmukulasta tytärmukuloihin ilman kuorirokkosienen läsnäoloa. Viroottisten tytärmukuloiden osuus vaihteli lajikkeittain. Tämä tulos korostaa entisestään sitä, että viruksettoman siemenperunan käyttö on tärkeä keino maltokaariviruksen leviämisen estämiseksi.

Maltokaarivirus kertyi kokeessa kaikkiin perunakasvin maanalaisiin osiin. Virus voitiin havaita myös perunan lehdistä, mutta pitoisuudet olivat hyvin pieniä. Perunan lehdet pystyvät ilmeisesti puolustautumaan maltokaarivirusta vastaan tehokkaammin kuin maanalaiset osat. Tehokkaampi puolustus saattaa selittyä erilaisilla olosuhteilla, jotka kohdistuvat perunan eri osiin. Maanpäälliset osat saavat valoa ja myös enemmän lämpöä kuin maanalaiset osat, mikä tehostaa viruspuolustusta. Itukokeissa osoitettiin, että lämpö ja valo yhdessä laskevat maltokaariviruspitoisuutta niille altistetuissa kasvinosissa. Syy eri kasvinosien erilaiseen tehokkuuteen puolustuksessa maltokaarivirusta vastaan saattaa olla RNA-hiljennysmekanismissa. RNA-hiljennyksen on aiemmin osoitettu toimivan tehokkaammin lämpimässä (Szittya et al. 2003).

Lisätukea RNA-hiljennyksen erilaiseen tehokkuuteen kasvin eri osissa on saatu siirtogeenisellä Nicotiana benthamiana-kasvilla ja perunalla tehdyissä kokeissa (Germundsson et al. 2002). Niissä on todettu, että kuoriproteiinigeeniin perustuva resistenssi toimii maltokaarivirusta vastaan tehokkaammin $N$. benthamianan lehdissä kuin juurissa. Samassa tutkimuksessa osoitettiin, että kuoriproteiinigeeniin perustuva resistenssi saattaa aiheutua RNA-hiljennyksestä, sillä maltokaariviruksen RNA:ta havaittiin huomattavasti vähemmän (tai ei lainkaan) siirtogeenisen $N$. benthamianan lehdissä verrattuna siirtogeenittömään kasviin. Tutkimuksessa osoitettiin myös, ettei siirtogeeni kyennyt vähentämään maltokaariviruspitoisuutta perunan mukuloissa. Tämän aiemman tutkimuksen pohjalta voidaan ajatella, että RNA-hiljennys on syynä havaittuun maltokaariviruspitoisuuden laskuun iduissa. Tältä osin tutkimukset ovat vielä kesken Mikäli RNA hiljennys osoittautuu syyksi maltokaariviruksen pienempään kertymiseen perunan maanpäällisiin osiin, voitaneen hiljennystä tehostaa tietyin menetelmin myös kasvin maanalaisissa osissa.

\section{Kirjallisuus}

Björnstad, A. 1969. Spredning av potet-mop-topp-virus (PMTV) med settepotater. Jord og avling 2: 2-4.

Caldo, R.A., Nettleton, D. \& Wise, R.P. 2004. Interaction-dependent gene expression in Mla-specified response to barley powdery mildew. Plant Cell. 16(9): 2514-28.

Calvert, E.L. \& Harrison, B.D. 1966. Potato mop-top a soil-borne virus. Plant. Path. 15(3): 134-139. 
Germundsson, A., Sandgren, M., Barker, H., Savenkov, E.I. \& Valkonen, J.P.T. 2002. Initial infection of roots and leaves reveals different resistance phenotypes with coat protein gene-mediated resistance to Potato mop-top virus. J. Gen. Virol. 83: 1201-1209.

Harrison, B.D. \& Jones, R.A.C. 1970. Host range and some properties of potato mop-top virus. Ann. Appl. Biol. 65: 395-402.

Jones, R.A.C. \& Harrison, B.D. 1969. Behaviour of potato mop-top virus in soil and evidence for its transmission by Spongospora subterranea (Wallr) Lagerh. Ann. Appl. Biol. 63(1): 1-8.

Kurppa, A. 1989a. The distribution and incidence of Potato mop-top virus in Finland as determined in 1987 and on the variation of disease symptoms in infected potatoes. Annales Agriculturae Fenniae 28: 285-295.

Kurppa, A. 1989b. Reaction of potato cultivars to primary and secondary infection by potato mop-top furovirus and strategies for virus detection. EPPO Bulletin 19: 593-598.

Nielsen, S.L. \& Mølgaard, J.P. 1997. Incidence, appearance and development of potato mop-top furovirusinduced spraing in potato cultivars and the influence on yield, distribution in Denmark and detection of the virus in tubers by ELISA. Potato Res. 40 (1): 101-110.

Ryden, K., Eriksson, B. \& Insunza, V. 1986. Rostringar hos potatis ursakade av potatismopptoppvirus (PMTV). Växtskyddsnotiser 50: 97-102.

Sandgren, M. 1995. Potato mo-top virus (PMTV): distribution in Sweden, development of symptoms during storage and cultivar trials in field and glasshouse. Potato Res. 38: 387-397.

Sandgren, M., Plaisted, R.L., Watanabe, K.N., Olsson, S. \& Valkonen, J.P.T. 2002. Evaluation of some North and South American potato breeding lines for resistance to Potato mop-top virus in Sweden. Am J Potato Res 79: 205-210.

Szittya, G., Silhavy, D., Molnar, A., Havelda, Z., Lovas, A., Lakatos, L., Banfalvi, Z. \& Burgyan, J. 2003. Low temperature inhibits RNA silencing-mediated defence by the control of siRNA generation. The EMBO Journal 22(3): 633-640. 